\title{
TERÉNNÍ VÝUKA ZEMĚPISU PRO ZÁKLADNÍ ŠKOLY: REALIZACE NA JEŠTĚDU
}

\author{
Artur Boháćč ; Zuzana Jelínková ${ }^{2}$ \\ Technická univerzita v Liberci, \\ Fakulta př́rodovědně-humanitní a pedagogická, Katedra geografie, \\ Komenského 314/2, 46001 Liberec, Česká republika \\ e-mail: ${ }^{1}$ artur.bohac@tul.cz; ${ }^{2}$ zuzana jelinkova@ hotmail.com
}

\begin{abstract}
Př́spěvek čtenáři předkládá aktuální problematiku terénní výuky na základní škole, konkrétně terénní výuky zeměpisu. Na realizaci terénní výuky mnohdy nezbývá čas nebo se jí učitelé kvůli její náročnosti vyhýbají. Terénní výuka je přitom zakotvena v Rámcovém vzdělávacím programu pro základní vzdělávání a její benefity pro žáky jsou nezpochybnitelné. Autoři na př́kladu hory Ještědu dokazují, že dostatek podnětů pro terénní výuku se nachází mnohdy nedaleko od školních budov, tudíž se minimalizuje časová i finanční náročnost takovéto výuky. V úvodních kapitolách příspěvku autoři představují teoretická východiska terénní výuky v geografickém vzdělávání a věnují se jejímu postavení v Rámcovém vzdělávacím programu pro základní vzdělávání. Následně analyzují na základě šetření aktuální řešení terénní výuky na základních školách v Liberci. Nejdůležitější částí příspěvku je komplexní plán terénní výuky na Ještědu. Vzhledem $\mathrm{k}$ tomu, že tato výuka již byla realizována, je autory evaluována. Součástí př́spěvku je mapa lokality výuky a ukázky z pracovního listu pro žáky.
\end{abstract}

\section{Keywords}

Project; Physical geography; Fieldwork; Locality; Framework Educational Programme.

\section{Úvod}

Př́spěvek vychází z projektu terénní výuky zeměpisu Poznej svůj Liberec, který je od záríí roku 2018 řešen na Katedře geografie Technické univerzity v Liberci (TUL) v rámci projektu Učitelem moderně a odborně. Projekt Poznej svůj Liberec navazuje na stejnojmennou bakalářskou práci Zuzany Jelínkové, vedenou Arturem Boháčem. Autorka tíhla $\mathrm{k}$ užitečné práci, která pomůže při řešení problémů výuky na základních školách, se zaměřením na zeměpis, město Liberec a jeho zázemí. Během jedenáctileté učitelské praxe na základní škole byla autorka několikrát svědkem toho, když ředitel školy řeší, jak vyplnit pro žáky dny, kdy není z nějaké př́činy možná výuka, ale již nemá k dispozici ředitelská volna. Její práce, resp. projekt, by měl sloužit právě k účelu vyplnění volných dnů a to díky své všestrannosti, mezipředmětovým vazbám a návaznosti na RVP ZV (Rámcový vzdělávací program pro základní vzdělávání Ministerstva školství, mládeže a tělovýchovy ČR). Dále by měl vyřešit v dnešní době diskutovanou terénní výuku, jež je součástí RVP ZV a jíž se stále velké množství učitelů snaží vyhýbat, a to nejčastěji $\mathrm{z}$ důvodů časové náročnosti, vlastní nezkušenosti či obav $\mathrm{z}$ ohlídání bezpečnosti žáků $\mathrm{v}$ terénu. Nelze též pominout laxnost a nechut' zavádět inovace, $v$ tomto př́padě učení praxí, u některých pedagogů. Terénní výuka je prritom přirozenou součástí výuky zeměpisu a činí ji atraktivnější. Pro žáky je přínosné poznat místo svého bydliště a okolí přímo a nejen z knih, výkladu a vyprávění, a uvědomit si změny, které v tomto místě probíhají. Složitá realita současného světa je velmi proměnlivá. Projekt zahrnuje pracovní list pro žáky, metodickou př́ručku pro učitele, jež je vodítkem pro jejich výklad v terénu, a mapu lokality Ještěd. Hojně se pracuje s badatelským pojetím výuky a moderními technologiemi. 
Vizí projektu Poznej svi̊j Liberec je seznamovat žáky v roce 2019 se třemi lokalitami, a to Ještědem, centrem Liberce a Bedřichovem, přičemž na Ještědu by se žáci zaměřovali na fyzickou geografii, v Liberci na humánní geografii a v Bedřichově na veškeré geografické fenomény. Nicméně, dosud byla zevrubně zpracována lokalita Ještěd zaměřená na fyzickou geografii.

\section{Cíle výzkumu}

Hlavním cílem př́spěvku je vytvoření konceptu terénní výuky na Ještědu, který napomůže v řešení otázky terénní výuky zeměpisu základním školám z Liberecka. Mezi klíčové aspekty konceptu patří pracovní list, metodická př́ručka pro učitele, příslušná mapa a v neposlední řadě zapojení proškolených budoucích pedagogů, kteří dohlížejí na průběh akce v lokalitě. Hlavní cíl se skládá z několika dílčích cílů, kterými jsou:

- shrnutí důvodů, proč je terénní výuka zeměpisu důležitá, opřené o relevantní informační zdroje

- zjištění aktuálního řešení terénní výuky na základních školách Liberecka

- vytvoření pomůcek, které usnadní výuku - jde o pracovního list, metodickou př́ručku pro učitele a mapu lokality Ještědu s vyznačenými stanovišti a body zájmu

- zhodnocení celého konceptu na základě proběhlé výuky

\section{$2 \quad$ Metody výzkumu}

Pro naplnění vytyčených cílů bylo nutné provést:

- rešerše české a zahraniční odborné literatury, zaobírající se tématem terénní výuky, a kurikulárních dokumentů

- výzkum stavu řešení tohoto typu výuky formou dotazníkového šetření na základních školách v Liberci a okolí - Zvolena byla forma kvantitativní pro postižení množství a frekvence zkoumaného jevu i kvalitativní pro hodnocení vybraného jevu.

- terénní průzkum na Ještědu - spojený s hledáním míst vhodných pro názornou výuku zeměpisu v souladu s tím, co se nachází v RVP ZV (očekávané výstupy) a jaké úkoly jsou v místech proveditelné.

\section{Teoretická východiska terénní výuky zeměpisu}

Terénní výuka je fenoménem, jež přináší různorodé terminologické, metodologické i praktické problémy. Pojem terénní výuky definuje Hofmann [3, s. 6] jako komplexní výukovou formu, která $\mathrm{v}$ sobě zahrnuje různé metody (pokus, laboratorní činnosti, pozorování, projektovou metodu, kooperativní metody, metody zážitkové pedagogiky) a různé organizační formy výuky (vycházku, terénní cvičení, exkurzi, tematické školní výlety - expedice), přičemž těžiště spočívá v práci mimo školu. Marada [8] vnímá terénní výuku jako formu vyučování, která vede žáky k sledování přírodních a společenských procesů, jejich rozmístění a projevům v krajině. Upozorňuje též na rozvoj celé řady potřebných dovedností a výchovný potenciál výuky zejména u zaměření na místní region žákủ. Terénní výuka tvoří doplnění verbálně sdělovaných faktů ve škole. Pro terénní výuku existuje spousta pojmů jako vyučování v terénu, terénní cvičení, terénní praktikum či výzkum, naučná vycházka, exkurze či geografická laboratoř, přičemž se v určitých nuancích odlišují. Např. naučná vycházka by měla být časově i odborně méně náročná než exkurze. Geografickou laboratoří jsou myšleny pravidelné vzdělávací vycházky do okolí budovy školy v délce jedné vyučovací hodiny. V dnešní době se terénní výuka stává součástí projektových dnů, které jsou nejkomplexnější výukovou metodou a měly by vést $\mathrm{k}$ činnostem vyžadujícím aktivitu žáků, získávání informací, jejich hodnocení a prezentaci výsledků [7]. V zahraniční literatuře existuje pro 
terénní výuku pojem fieldwork. Rověž se vyskytuje termín field trip, který je exkurzí, pro níž je klíčové pozorování a testování hypotéz v reálném světě. Můžeme se také setkat s pojmem excursion [3, s. 269]. Angloamerické vzdělávací prostředí je inspirací nejen po stránce terminologické, ale též ve vysoké míře využívání terénní výuky. Terénní výuka se může zabývat širokou paletou zeměpisných témat z podoborů fyzické geografie, kartografie a geoinformatiky nebo humánní geografie a může dokonce organicky propojovat různé školní předměty.

Formy terénní výuky jsou odvislé od jejích cílů. Hofmann a kol. [4] dělí terénní výuku ze čtyř hledisek:

- z hlediska časového - rozlišujeme krátkodobou (několikahodinovou), střednědobou (jednodenní) a dlouhodobou (vícedenní) výuku

- z hlediska krajiny, ve které výuka probíhá - rozlišujeme krajinu př́rodní více či méně pozměněnou, krajinu kulturní více či méně pozměněnou, silně pozměněnou, městskou a venkovskou

- $\quad$ z hlediska vedení výuky - výuku vedou bud’ žáci, učitel nebo žáci v kooperaci s učitelem (podobně lze variovat i v otázce hodnocení výuky)

- $\mathrm{z}$ hlediska harmonogramu výuky - rozlišujeme přípravu učitele v terénu i rešeršemi, přípravnou fázi žáků spojenou s motivací, zapojením do organizace výuky a seznámení s místem výuky, realizační fázi v terénu a závěrečnou fázi zpracování úkolů, interpretace výsledků a hodnocení výuky

Plánování terénní výuky souvisí s invencí pedagoga. Častý je takový postup, kdy se dozví o nějakém problému či zajímavosti s prostorovými aspekty a vyrazí na terénní průzkum. Hledá místa vhodná jako stanoviště terénní výuky. Poté je téma pomocí studia literatury rozpracováno a doporučeny jsou konzultace s odborníky (např. učiteli jiných vyučovacích předmětů) [8]. Pro terénní výuku je klíčové stanovení realistických cílů, jasných a ne př́liš obecných, aby bylo možno hodnotit efektivitu výuky [7, s. 24]. Doporučuje se evaluovat pracovní list, závěrečné práce, mapy či jiné výstupy žáků podle předem daných kritérií. Z obecnějšího hlediska se snaží autoři př́íspěvku vycházet $\mathrm{z}$ revidované Bloomovy taxonomie a postupovat od nižších kognitivních cílů až $\mathrm{k}$ těm nejvyšším [12, s. 16]. I proto došlo k zařazení badatelského pojetí výuky (angl. inquiry-based learning nebo též learning by doing) spojeného s individuálními i týmovými zážitky, vedoucími k umění identifikace a řšení problémů, zapamatování učiva a probouzení zájmu o zeměpis [11]. V zeměpisu má badatelská výuka vést k pochopení jedinečnosti zkoumaného místa (genius loci) a aspektů, kterými se liší od okolních míst. Badatelská výuka počítá s minimálními zásahy pedagoga do samotného zkoumání. Př́nosem je pro žáky praktické využití nejen zeměpisných znalostí nabytých při výuce ve školní třídě. Terénní výuka je pro pedagogy náročnější než výuka ve tř́dě z hlediska časové a finanční náročnosti, otázek bezpečnosti, avšak autoři jsou přesvědčeni o tom, že tyto zápory jsou překonány výše zmíněnými pozitivy.

$\mathrm{V}$ předloženém textu autoři pracují se střednědobou terénní výukou $\mathrm{v}$ méně pozměněné kulturní krajině, spadající z naprosté většiny do katastru města Liberce (městské čtvrti Horní Hanychov a Hluboká), částečně do katastru obce Světlá pod Ještědem. Krajinný ráz území je však spíše venkovský. Organizaci výuky zajišt'uje z hlediska základních škol externí subjekt, nicméně role učitele je stale důležitá při motivaci žáků, výkladu a diskusi nad zjištěnými fakty se žáky. Předložená koncepce terénní výuky je dobře hodnotitelná díky pracovním listům a závěrečnému sezení. 


\section{Zeměpis a jeho terénní výuka v RVP ZV}

RVP ZV je základní kurikulární dokument. Autoři pracují s jeho poslední aktualizací z roku 2017, jež vymezuje devět vzdělávacích oblastí. Každá vzdělávací oblast je tvořena blízkými vzdělávacími obory, které se mohou prolínat. Zeměpis spadá do oblasti Člověk a př́roda, ale vzhledem $\mathrm{k}$ jeho akcentu na prostorové aspekty nelze nevidět jeho přesahy do dalších oblastí jako Člověk a společnost i dalších. Zaměření vzdělávací oblasti determinují, jakým směrem je žák veden, aby dosahoval klíčových kompetencí - kompetence k učení, kompetence k řešení problémů, kompetence komunikativní, kompetence sociální a personální, kompetence občanské a kompetence pracovní. Klíčové kompetence mají žáka připravit na problémy každodenního života, úkoly v zaměstnání, a mají být náhradou určitého encyklopedismu, který je v českém vzdělávání stále zakořeněn.

Vzdělávací oblast Člověk a př́roda (vzdělávací obory Fyzika, Chemie, Přírodopis, Zeměpis) se zabývá člověkem, přirodou a jejich interakcí. Cíli této vzdělávací oblasti jsou poznání př́rody jako celku, vytváření otevřeného myšlení, osvojení poznávacích metod, rozvoj poznávací dovednosti, experimentování, vytváření a ověřování hypotéz, poznání složitosti a souvislosti mezi př́rodou a lidskou činností. Vzdělávací oblast poskytuje př́ležitost poznávat př́rodu jako dynamický celek plný složitých vazeb. Dává žákům potřebný základ pro lepší pochopení a využívání současných technologií a pomáhá jim s orientací v každodenním životě. Nejvýznačnějšími postupy (a rozvíjenými dovednostmi) žákủ jsou soustavné a spolehlivé pozorování, experimentování a měření. Na základě těchto poznatkủ o pozorovaném prŕrodním jevu rozvíjejí dovednost vytváření a ověřování hypotéz, analýzy výsledků tohoto ověřování a vyvozování závěrů. V RVP ZV je u oblasti Člověk a př́roda přímo zmíněn žádoucí badatelský charakter výuky [10].

Součástí vzdělávacího oboru Zeměpisu je dle RVP ZV vzdělávací obsah Terénní geografická výuka, praxe a aplikace. Má zahrnovat:

- cvičení a pozorování v terénu, geografická exkurze - obsahují orientační body, jevy, pomůcky a př́stroje, stanovišše, určování hlavních a vedlejších světových stran, pohyb podle mapy a azimutu, odhad vzdálenosti a výšek objektů v terénu, jednoduché panoramatické náčrtky krajiny, situační plány, schematické náčrtky pochodové osy a hodnocení prírodních jevů a ukazatelů

- ochrana člověka při ohrožení zdraví a života - jde o vysvětlení živelních pohrom, opatření proti nim, chování a jednání při nich v modelových situacích

Od žáka se pak očekává, že ovládá základy topografie a orientace v terénu a aplikuje v terénu praktické postupy při pozorování, zobrazování a hodnocení krajiny. Dále žák uplatňuje v praxi zásady bezpečného pohybu a pobytu v krajině, uplatňuje v modelových situacích zásady bezpečného chování a jednání při mimořádných událostech. Na minimální doporučené úrovni žák ovládá základy praktické topografie, orientace $\mathrm{v}$ terénu a uplatňuje v praxi zásady bezpečného pohybu a pobytu ve volné př́rodě [10].

\section{5 Řešení terénní výuky zeměpisu na základních školách na Liberecku}

Každá základní škola je povinna sestavit dle RVP své školní vzdělávací programy (ŠVP), tudíž navrhnout řešení terénní výuky spolu s jejími očekávanými výstupy. Bylo provedeno dotazníkové šetření na libereckých základních školách, řešící postavení terénní výuky v rámci zeměpisu a jeho mezipředmětových vazeb. Šlo o to zjistit, jaký podíl učitelů terénní výuku uplatňuje a jakými způsoby, a objasnit, proč se někteří učitelé terénní výuce vyhýbají. Posledním cílem šetření bylo zjistit, zda by byl projekt Poznej svioj Liberec žádaný. Stručný dotazník, jehož vyplnění nemělo respondentům zabrat více než 10 minut, obsahoval uzavřené 
i otevřené otázky. Z dvaadvaceti oslovených základních škol Liberecka, Turnovska a Hrádecka, resp. učitelů zeměpisu, se písemného dotazníkového šetření zúčastnilo pouze deset z nich. Na první pohled nízká návratnost dotazníků se ukázala být nadprůměrnou, bylali srovnána s obdobnými výzkumy [6].

Bylo zjištěno, že terénní výuka se nejčastěji naplňuje v 9. a 6. ročníku. Nejčastější formou terénní výuky je vycházka do okolí budovy školy a poté školní výlet. Způsobů, kterým lze naplňovat výuku v terénu, uvedli respondenti několik, a to $\mathrm{v}$ různých kombinacích. Uváděli exkurze, projekty nebo rozličné pobytové kurzy (škola v přírodě, lyžařský kurz, cyklistický kurz apod.). Terénní výuka zeměpisu bývá naplňována i v rámci jiných předmětů, nejčastěji př́rodopisu, chemie, fyziky a občanské nauky. Všech deset respondentů shodně uvedlo, že se snaží výuku v terénu naplňovat alespoň tím, že žáky v blízkém okolí školy seznámí s prací s mapou. Jde tedy o formu geografické laboratoře. Nicméně, šest respondenti̊ uvedlo, že nemá dostatek časové dotace na svůj vlastní předmět, natož provádění delší výuky v terénu. Dalším problémem je finanční a organizační náročnost, spojená s nižší disciplínou žáků v terénu, takovéto formy vyučování. Jako další komplikaci tři respondenti uvedli, že sami mají problém učit $\mathrm{v}$ terénu, a proto se terénní výuce záměrně vyhýbají. Dotazníkové šetření potvrdilo celorepublikový trend nárůstu využívání terénní výuky, ale odhalilo i bariéry jejího zařazování [5]. Polovina respondentů by bezvýhradně uvítala realizaci terénní výuky v rámci projektu Poznej svi̊j Liberec, a to hlavně z důvodu formy, připravenosti pracovního listu a mezipředmětových vazeb, které projekt nabízí. Váhavost ostatních respondentů s využitím projektu souvisela převážně $\mathrm{s}$ tím, že $\mathrm{v}$ době konání průzkumu šlo o projekt $\mathrm{v}$ rámci absolventské práce. Kooperaci by se nebránili, kdyby projekt zaštit’ovala např. Katedra geografie TUL.

Tab. 1: Př́klad harmonogramu rozdělení učiva zeměpisu na základníškole

\begin{tabular}{|l|l|l|l|}
\hline 6. ročník & 7. ročník & 8. ročník & 9. ročník \\
\hline $\begin{array}{l}\text { planeta Země } \\
\text { glóbus Země } \\
\text { př́rodní obraz Země } \\
\text { zeměpis světadílů }\end{array}$ & $\begin{array}{l}\text { zeměpis světadílů } \\
\text { zeměpisná cvičení }\end{array}$ & $\begin{array}{l}\text { krajina a životní } \\
\text { a pozorostředí }\end{array}$ & Česká republika \\
v krajině & $\begin{array}{l}\text { Země, planeta lidí } \\
\text { politické rozdělení }\end{array}$ & \\
\hline
\end{tabular}

Zdroj: [13]

Tab. 2: Možnosti realizace terénni výuky dle probraného učiva zeměpisu na ZŠ

\begin{tabular}{|l|l|l|}
\hline \multirow{2}{*}{ 6. ročník } & \multicolumn{2}{|l|}{ Období realizace projektu } \\
\cline { 2 - 3 } & září - říjen & duben - červen \\
\hline 7. ročník & krajinná sféra & $\begin{array}{l}\text { georeliéf } \\
\text { zeměpisná pozorování v krajině }\end{array}$ \\
\hline 8. ročník & $\begin{array}{l}\text { georeliéf } \\
\text { zeměpisná pozorování } \\
\text { v krajině }\end{array}$ & $\begin{array}{l}\text { krajina } \\
\text { krajina a životní prostředí } \\
\text { zeměpisná pozorování v krajině }\end{array}$ \\
\hline 9. ročník & $\begin{array}{l}\text { poloha a rozloha } \\
\text { př́rodní prostředí }\end{array}$ & $\begin{array}{l}\text { př́rodní prostředí } \\
\text { obyvatelstvo a sídla } \\
\text { oblasti České republiky - severní Čechy } \\
\text { zeměpisná pozorování v krajině }\end{array}$ \\
\hline
\end{tabular}

Zdroj: Vlastní zpracování

Vlastní průzkum obsahu ŠVP na základních školách v Liberci potvrdil téměř totožný harmonogram rozložení kmenového učiva na ZŠ (viz Tab. 1). Na základě tohoto zjištění bylo navrženo období realizace terénní výuky v lokalitě Ještěd v souladu s ŠVP zapojených škol tak, aby fungovala návaznost na probrané učivo v praxi (viz Tab. 2). Dalším faktorem, který 
byl brán v potaz, bylo klima lokality Ještěd, která se nachází v chladné podnebné oblasti, a proto zde není možná celoroční realizace.

\section{Geografické vymezení lokality Ještěd}

Hora Ještěd s budovou vysílače na vrcholu, tvořeného křemencovým sukem, je symbolem Liberce, který se vyskytuje v množství log libereckých subjektů, propagačních materiálů ad. Lokalita Ještěd se nachází v oblasti Ještědsko-kozákovského hřbetu, jihozápadně od centra města Liberce, v Paseckém hřbetě, jenž sousedí na východě s Libereckou kotlinou (Žitavská pánev), na jihozápadě s Kotelskou vrchovinou (Ralská pahorkatina), na severu s Kryštofovými hřbety (Ještědsko-kozákovský hřbet) a na jihovýchodě s Rašovským hřbetem (Ještědsko-kozákovský hřbet) [1]. Celá lokalita se nachází v území Přírodního parku Ještěd, kromě Naučné stezky (NS) Padáky - Ještědský paradox. V Přírodním parku Ještěd se kromě naučných stezek nacházejí i dvě prírodní památky (PP). Stezky jsou lemovány množstvím informačních tabulí, vytvořených Libereckým krajem, Městskými lesy Liberec a Jizerskoještědským spolkem, $\mathrm{z}$ nichž autoři také čerpali. Lokalita Ještěd tedy zahrnuje řadu chráněných území:

- PP Terasy Ještědu - má výměru 120,96 ha a nachází se v katastrálním území obcí Světlá pod Ještědem, Kryštofovo Údolí a města Liberce v nadmořské výšce od 769 m do 1012 m n. m. Předmětem této př́rodní památky jsou mrazovými procesy vzniknuvší terasy, izolované skály (např. Krejčík u stanice lanové dráhy na vrcholu Ještědu), sut'ové pole a další geomorfologické útvary, které vznikly v předpolí evropského pevninského ledovce ve starších čtvrtohorách. Předmětem výuky v této lokalitě jsou Víŕivé kameny a sut'ové pole spolu s glaciálními relikty bezobratlých živočichů, napřr. pavouk Wubanoides longicornis, střevlík Pterostichus negligens nebo mechy a játrovky. Vrchol Ještědu, ostrůvek přirozeného bezlesí subalpínského stupně, je mimo Krkonoš unikátním biotopem z hlediska Libereckého kraje. Z bylin zde roste plavuň pučivá, podbělice alpská, kýchavice bílá Lobelova nebo zlatobýl alpínský. Z dřevin jeřáb ptačí olysalý nebo nepůvodní kleč. V přilehlých smrkových porostech hnízdí čečetka zimní, hýl obecný a krkavec velký [9]. V přírodní památce se nachází stejnojmenná naučná stezka.

- PP Panský lom - př́rodní památka Panský lom (vyhlášena v roce 2005) se nachází v katastrálním území města Liberce v nadmořské výšce 600 m. Hluboký opuštěný lom poskytuje jeden $\mathrm{z}$ nejúplnějších profilů devonského vápencového sledu Ještědského pohoří a ukázky př́kře vztyčených vrstev s detailním provrásněním. Byla zde nalezena rezidua schránek zkamenělých ramenonožců, což dokazuje dávnou přítomnost moře v lokalitě. Vylouhováním vápence podle puklin vznikla Hanychovská jeskyně, která je prrístupná veřejnosti poslední víkend v měsíci srpnu a je zároveň sídlištěm a zimovištěm netopýrů.

- NS Terasy Ještědu - trasa této naučné stezky je dlouhá $10 \mathrm{~km}$ a vede po nejzajímavějších skalních útvarech Ještědského hřebene. Má 12 zastavení, která návštěvníky seznamují především s geologií a geomorfologií Ještědského hřebene, s historií lanové dráhy na Ještěd, s historií ještědských chat, hotelů a pomníčků. Jedno zastavení je věnováno také spisovatelce Karolíně Světlé. Součástí této NS jsou stanoviště vrchol Ještědu, sut'ové pole, lanovka Skalka, 15. poledník.

- NS Ještědské vápence - trasa stezky je $12 \mathrm{~km}$ dlouhá, seznamuje návštěvníky na svých 12 zastaveních s geologií, geomorfologií, flórou, faunou a historií Ještědského hřebene. PP Panský lom je součástí NS Ještědské vápence. Stejně tak stanoviště Panský lom a Pláně pod Ještědem. 
- NS Padáky - Ještědský paradox - trasa má délku $1 \mathrm{~km}$ a navazuje na hranici Př́rodního parku Ještěd u sportovního areálu. Protíná velmi strmou bývalou sjezdovku Padáky. Předmětem NS je blízký les, který se na první pohled liší od ostatních hospodářsky využívaných porostů svou skladbou. NS seznamuje návštěvníky s fungováním přirozeného lesního ekosystému. Věková struktura porostu se pohybuje od 0 do 170 let, významné zastoupení zde má buk lesní, javor klen a smrk ztepilý. NS Padáky jsou stanovištěm terénní výuky.

Vrcholu Ještědu lze dosáhnout pěšky využitím turistických pěších tras a naučných stezek (NS), kabinovou lanovou dráhou nebo autem na parkoviště Ještědka a poté pěšky po silnici k vrcholu. Pro účely výuky je autory doporučeno využít lanové dráhy z Horního Hanychova na vrchol Ještědu nebo s ohledem na počasí, finance, časové možnosti či fyzickou kondici žáků zvolit náročnější trasu výstupu přes Výpřež nebo velmi náročnou trasu vedle sjezdovky naučnou stezkou Padáky. Terénní výuka v lokalitě Ještěd zahrnuje celkově pět tras, pět variací pořadí a složení celkového počtu osmi stanovišt' k výběru (viz Fig. 1). Je tedy možné přizpůsobit výuku požadavkům a možnostem jednotlivých škol. Všechny trasy zahrnují stanoviště Horní Hanychov, konečnou stanici tramvaje č. 3, a vrchol Ještědu. Časová náročnost všech pěti tras které jsou v rámci projektu $\mathrm{k}$ dispozici, činí 5-7 hod. a délka tras je 7-11,5 km. Lokalita Ještěd skýtá nejen z geografického hlediska zajímavé a pestré prostředí, pro školy z Liberecka je dobře dopravně dostupná a je relativně bezpečná.

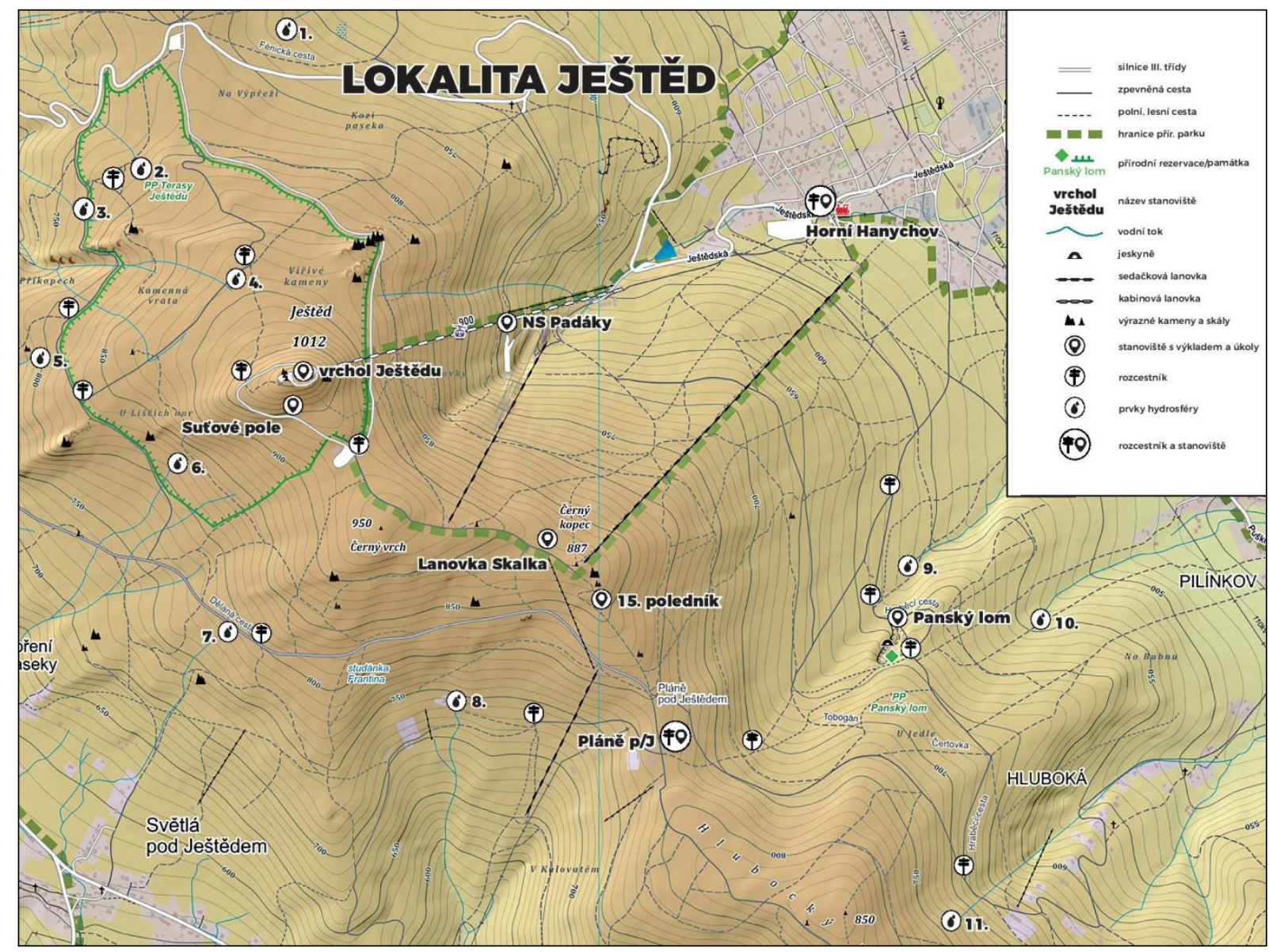

Zdroj: Vlastní zpracování, Kristýna Onallah, seznam.cz

Fig. 1: Mapa lokality Ještěd 
Zeměpis lze během terénní výuky názorně a efektivně propojit s dalšími školními předměty, přičemž se žáci učí pracovat s metodami jednotlivých předmětů (vědních oborů), kombinovat je a prredevším vnímat řešený problém $v$ jeho celistvosti bez roztř̌ššěnosti do jednotlivých vyučovacích předmětů. Žáci tak nezískávají pouze geografické znalosti a dovedností, jakými jsou orientace v prostoru, práce s mapou, měření dat a zaznamenávání informací různorodými způsoby. Níže jsou uvedeny vzdělávací oblasti, kterých se terénní výuka na Ještědu dotýká.

\subsection{Vzdělávací oblast Člověk a př́íroda}

Fyzika - žáci změří různé fyzikální veličiny na určených stanovištích dle itineráře trasy:

- teplota vzduchu $\left[{ }^{\circ} \mathrm{C}\right]$ - měřena digitálním teploměrem, čidlem meteostanice nebo speciálními př́stroji, jako je SPARK Science Learning System od firmy Pasco, jenž je velmi vhodný pro badatelskou výuku $\mathrm{v}$ prrírodních vědách

- vlhkost vzduchu [\%] - měřena čidlem meteostanice nebo přístrojem SPARK

- atmosférický tlak [hPa] - měřen na určených stanovištích mobilní aplikací (Barometer) nebo prístrojem SPARK

- rychlost větru [m/s] - měřena pomocí aplikace $\mathrm{v}$ mobilním telefonu či tabletu (Zephyr Free Wind Meter) nebo př́istrojem SPARK

- směr větru $[\mathrm{S}, \mathrm{V}, \mathrm{J}, \mathrm{Z}, \mathrm{SV}, \ldots]$ - měřen pomocí vyrobené směrovky, buzoly a směru ohybu stromů, vlání vlajek nebo igelitového sáčku přivázaného na větvičku

- hluk $[\mathrm{dB}]$ - měřen aplikací v mobilním telefonu (Decibelmeter) v decibelech

Chemie - žáci provedou tyto úkoly:

- změří $\mathrm{pH}$ půdy - měřeno v roztoku odebraného vzorku půdy s destilovanou vodou pomocí $\mathrm{pH}$ papírku

- změří $\mathrm{pH}$ vody v potocích, pramenech či kalužích - měřeno pomocí $\mathrm{pH}$ papírku

- provedou neutralizaci - na vzorek kamene obsahující vápenec je nastř́íkán $8 \%$ ocet (při obsahu vápence je vidět reakce - šumění a pozvolné rozpouštění)

- zjištění obsahu vápna v půdě - odebraný vzorek půdy nechají ve škole proschnout a po aplikaci $8 \%$ octu zjistí, zda je v půdě obsažen či ne (při obsahu vzorek půdy zašumí)

Všechna výše uvedená měření se zaznamenávají do tabulky v př́ručce, k některým z nich je připravena nápověda a návod ke srovnávání hodnot.

Př́rodopis - žáci se seznámí s místní faunou a flórou, vzácnými i ohroženými druhy.

\subsection{Vzdělávací oblast Matematika a její aplikace}

Matematika - žáci použijí jednoduché početní úlohy k:

- výpočtu průměrného kroku, který činí 42 \% výšky jedince [cm]

- výpočtu odhadové vzdálenosti dle průměrného kroku jedince

- výpočtu správného času v určených městech podle poledníků

- spočítání nadmořské výšky podle vrstevnic na mapě 


\subsection{Vzdělávací oblast Člověk a jeho svět}

Žáci se v terénu učí a získávají informace o:

- své obci (městě) - Libereci, Světlé pod Ještědem

- místní krajině Ještědského hřebene

- poloze obce (města) v krajině

\subsection{Vzdělávací oblast Člověk a společnost}

Žáci se v terénu učí o:

- zajímavých a památných místech

- ochraně přírodních památek (PP Terasy Ještědu, PP Panský lom)

\subsection{Vzdělávací oblast Člověk a zdraví}

Výchova ke zdraví - žáci během pobytu v terénu utužují vztahy:

- mezi sebou nebo v rámci vrstevnické skupiny

- ve dvojici či trojici při plnění úkolů

- se svým učitelem

Tělesná výchova - žáci si osvojují činnosti ovlivňující úroveň pohybových dovedností jako:

- slušné chování v dopravních prostředcích při přesunu

- pohyb v terénu

- ochrana př́rody

\subsection{Vzdělávací oblast Člověk a svět práce}

Žáci při pobytu v terénu při experimentech dodržují pravidla bezpečnosti práce a ochrany př́rody. Žáci používají různé technologie, at’ už mechanické, elektrické či softwarové, jako:

- př́stroj SPARK na měření rychlosti větru, teploty, vlhkosti vzduchu, atmosférického tlaku

- aplikace v mobilním telefonu Runkeeper, Zephyr WindFree Meter, Decibel Meter a Barometer

\section{Výukové materiály}

Pracovní list pro žáky (14 s.), metodický list pro učitele (26 s.) i mapa celé lokality Ještěd, která zahrnuje též alternativní trasy výstupu na vrchol hory, jsou vybaveny jednotnými piktogramy a obsahem úloh. Speciální piktogramy jsou přiděleny stanovištím $s$ více úkoly, turistickým rozcestníkům, prvkům hydrosféry a prvkům litosféry.

Pracovní list pro žáky zahrnuje úkoly vztahující se k osmi stanovištím, a to Horní Hanychov, NS Padáky (toto stanoviště je poněkud rozlehlejší, vzhledem k tomu, že jde o naučnou stezku), vrchol Ještědu, sut'ové pole, lanovka Skalka, 15. poledník, Pláně pod Ještědem a Panský lom a tři samostatné menší úlohy. Úlohy se týkají nejen konkrétních stanovišt' či hory Ještěd, ale také obecnějších záležitostí jako zeměpisná souřadnicová sít', počasí a podnebí, geologická stavba, hydrologické poměry aj. Autoři se vždy snaží v listech postupovat od obecného ke konkrétnímu a konkrétních záležitostí zapojovat pozorování, experimentování a měření. Důraz je rovněž kladen na komparaci získaných údajů. List 
obsahuje tabulku pro zanesení $\mathrm{v}$ terénu naměřených hodnot a důležité grafické př́ilohy znázorn̆ující typy oblak, stupnici kyselosti a zásaditosti, Beaufortovu stupnici rychlosti větru či hladinu hluku pro lepší pochopení textu.

Metodická prŕíručka pro učitele obsahuje na rozdíl od žákovského listu informace o vzdálenostech a časech souvisejících s připravenou terénní výukou. Žáky by tyto údaje mohly při plnění úkolů rozptylovat, nicméně ti nadanější je jsou schopni vyčíst $\mathrm{z}$ mapy lokality. Př́ručka rovněž zahrnuje výklad související s jednotlivými stanovišti, který je strukturován tak, že by ho měl pochopit a být schopen dále vysvětlit každý aprobovaný učitel zeměpisu. Dále obsahuje správné odpovědi pro vytyčené úkoly a seznam v listech využitých informačních zdrojů, mezi něž náleží kromě odborné literatury, informačních tabulí a specializovaných webových stránek i konzultace se specialistou na geologii. Nedílnou součástí príručky je seznam pomůcek pro úspěšnou terénní výuku. Jde o psací potřeby, kružítko, pásmo, lakmusové papírky, zkumavky, destilovanou vodu, lopatku, plastové sáčky, chirurgické rukavice, buzolu, stopky a meteostanici nebo jiný meteorologický př́ístroj. Dále je zapotřebí mít stažené potřebné aplikace $\mathrm{v}$ mobilních zařízeních. Tyto aplikace jsou pro mobilní telefony $\mathrm{s}$ operačním systémem Android zdarma. Telefony s tímto operačním systémem jsou v České republice oblíbené, tudíž není problém zajistit, aby byl v každé pracovní skupině minimálně jeden žák připravený měřit pomocí zmíněných aplikací. V prredchozí kapitole zmiňovaný přistroj SPARK dodávají organizátoři výuky. Metodická př́ručka pro učitele umožňuje pedagogovi minimalizovat čas na př́pravu výuky. Vzhledem $\mathrm{k}$ tomu, že je projekt směřován školám na Liberecku, počítá se $\mathrm{s}$ tím, že učitelé Ještěd znají. Nicméně, výklad, motivace žáků, interpretace výsledků a benefitů výuky stále zůstává z podstatné části na vyučujícím. Níže (viz Fig. 2 a Fig. 3) jsou ukázány vybrané strany z pracovního listu pro žáky. Zájemci o zaslání kompletních materiálů mohou kontaktovat autory prŕspěvku elektronickou poštou. 


\section{O STANOVIŠTĚ VRCHOL JEŠTĚdU}

1. výklad

$>$ přiřad' k sobě název území a pưvod jeho vzniku:
1. Ještědský hřbet
a) sopečný
2. Ralská pahorkatina
b) vrásový
3. Jizerské hory
c) kerný (zlomový)

2. práce s mapou - prvky hydrosféry a litosféry

$>$ dle mapy zařad', do jakého úmoří spadají označené vodní toky:

\begin{tabular}{|l|r|r|r|r|r|r|r|r|r|r|r|}
\hline \multicolumn{10}{|c|}{ Vodní toky v mapě } \\
\hline úmoří & 1 & 2 & 3 & 4 & 5 & 6 & 7 & 8 & 9 & 10 & 11 \\
\hline Severni moře & & & & & & & & & & & \\
\hline Baltské moře & & & & & & & & & & & \\
\hline
\end{tabular}

> najdi a označ modře v mapě:

- $\quad$ horní pramen Ploučnice, který se nachází severně od obce Hoření Paseky v nadmořské výšce 712 m

$M>$ najdi a označ hnědě na mapě:

- $\quad$ Vírivé kameny, které se nachází SSV od vrcholu Ještědu v nadmořské výšce $840-875$ m

- $\quad$ Sutové pole, které se nachází jižně od vrcholu Ještědu v nadmořské výšce $950 \mathrm{~m}$

\section{3. práce s buzolou}

azimut hory Ralsko z vyhlídkové terasy je

Fig. 2: Pracovní list pro žáky (stanoviště vrchol Ještědu) 


\section{O STANOVIŠTĚ PLÁNĚ POD JEŠTĚDEM}

\section{Výklad:}

\section{Počasí:}

Počasí je ovzduší na určitém místě,

tvoři se v troposféře, která je součástí Na počasí má

vliv: a)

b).
c)

d)

e)

\section{Oblaka:}

$\Rightarrow$ napiš, co znamenaji niže uvedené druhy oblak v češtinè

Cirrus

Stratus

$\Rightarrow$ napiš, jak se dèli oblaka dle výšky jejich výskytu

1)

3)

2)

u oblaků a patra se výška základny mění se nejniže bývá u pólů.

nejvýše u rovníku.

Fig. 3: Pracovní list pro žáky (stanoviště Pláně pod Ještědem) 
Autoři upozorňují, že koncept terénní výuky na Ještědu se stále vyvíjí a s ním pracovní list, metodická príručka pro učitele a př́slušná mapa. $\mathrm{S}$ každou provedenou terénní výukou se objevují možné inovace, opírající se zejména o vlastní pozorování a reakce učitelů zúčastnivších se škol.

Pilotní verze pracovního listu pro lokalitu Ještěd byla vytvořena během zpracovávání bakalářské práce $\mathrm{v}$ roce 2017. Byla určena pro žáky 9. ročníků základních škol, kteří již absolvovali vzdělávací obsah vzdělávacího oboru Zeměpis dle RVP ZV. Pilotní verze byla otestována dvěma základními školami. Na základě zpětné vazby učitelů zeměpisu byl pracovní list inovován a doplněn o úkoly zahrnující práci s moderními technologiemi. Nynější pracovní list byl nejdř́ve otestován a vyplňován členkami krasobruslařského klubu Variace Liberec, v němž autorka působí jako trenérka, žákyněmi 4., 5., 7. a 8. ročníku. Dívky aktivity bavily, především různá měření, a neměly s nimi větších potíží. Nejsou tedy nutně určeny výhradně žákům 9. ročníku. V záŕí roku 2018 byl aktuální pracovní list odzkoušen během terénní výuky, která se dosud nejvíce přibližovala představám autorů, a to na žácích 8 . a 9. ročníku ZŠ Kobyly (viz Fig. 4). Během výuky žákům i učitelům asistovaly a pomáhaly tři proškolené studentky magisterského studia učitelství zeměpisu na TUL a výuce byl prŕitomen odborný dohled z Katedry geografie TUL. Žáci i učitelé ze ZŠ Kobyly si výuku pochvalovali.

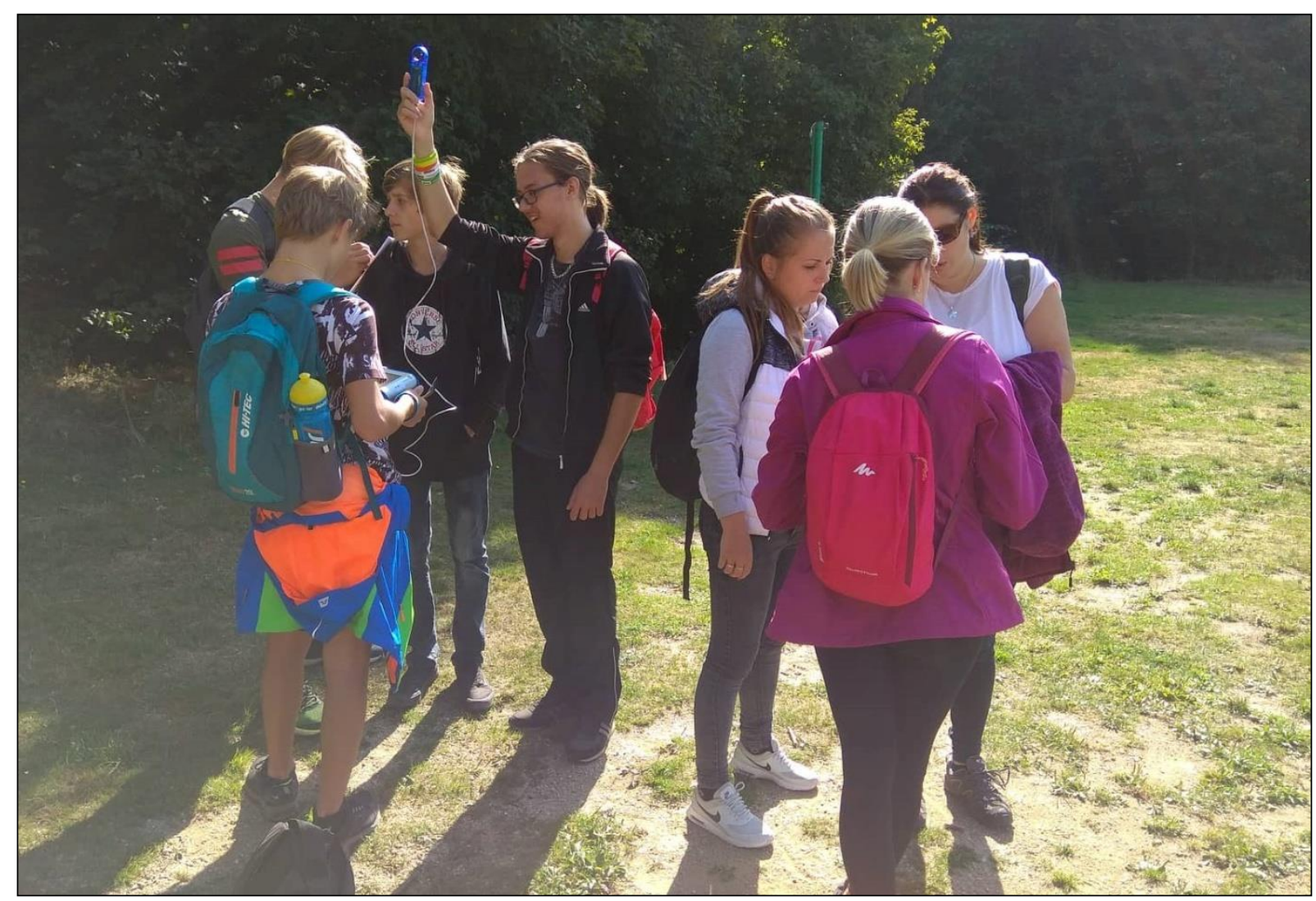

Zdroj: Vlastni

Fig. 4: Ž́áci ze ZŠ Kobyly (skupina vlevo) při měrení rychlosti větru přistrojem SPARK

Nicméně, během této výuky byly reflektovány některé nedostatky a úskalí. Většina žáků měla tendence se př́lišně soustředit na měření fyzikálních veličin, avšak nebyla schopna interpretovat fyzickogeografické souvislosti různých výsledků měření. To souvisí s faktem, že v klasické vyučovací hodině si žáci musejí složité procesy, jejich konotace a dopady pouze představovat. Pokud se o to vůbec snaží, bývají tyto představy mnohdy dost nepřesné. Následkem je, že v terénu nejsou schopni znalosti z klasické výuky aplikovat. Bylo navrženo 
řešení ve formě přidělení studenta magisterského studia učitelství zeměpisu ke každé skupině žáků, který by jim průběžně vysvětloval potřebné souvislosti. Personální pokrytí takovéto asistence by vzhledem $\mathrm{k}$ aktuálnímu počtu studentů nečinilo potíž, navíc by šlo o cennou zkušenost pro zapojené jednotlivce. Nešlo si nevšimnout, že celé skupiny žáků byly, co se týče znalostí, dovedností i motivovanosti odlišné. Složení těchto pracovních skupin je však záležitostí učitelů základních škol, jež s žáky dlouhodobě pracují a znají je.

Objevily se potíže žáků s měřením pH půdy, kdy bylo obtížné rozeznat zbarvení indikačního papírku od znečištění papírku od vzorku půdy. Papírek bylo nutno očistit, a přesto nebylo jeho zbarvení po měření výrazné, což je dáno tím, že půdy v lokalitě nejsou výrazně kyselé, ani zásadité. Pomoci by mohlo užívání indikačního papírku jiné barvy než žlutooranžové či měření speciálním přístrojem. Problém se znečištěním zeminou se vyskytoval rovněž u chemického pokusu s neutralizací vápence, když při této kontaminaci vápenec nereagoval. Žáci rovněž stř́kali ocet na kameny neobsahující vápenec. Opět je tedy třeba dbát na očištění vzorku od půdy, resp. na správné určení vápence pod dohledem proškolených studentů. Žáci nepředpokládaně pocítili klimatickou změnu, nebot' extrémně suché léto zapř́činilo nemožnost nalezení vody na stanovišti v Horním Hanychově. Slunný potok byl vyschlý a v blízkém okolí nebyla ani žádná louže. Cestou zpět byl nedaleko Panského lomu objeven přítok Plátenického potoka, ve kterém byla voda, a tak si žáci mohli měření $\mathrm{pH}$ vody vyzkoušet. V takovýchto krajních př́ípadech existuje u trasy zahrnující výjezd lanovou drahou na Ještěd možnost měření pH vody přesunout na závěrečné stanoviště Panský lom. Komplikovanější možností je úprava trasy tak, aby bylo navštíveno prameniště nad Výpřeží.

Návrhem pro zpestření terénní výuky je využití technologie GPS (Globální polohový systém). Žáci během výuky již pracují s mobilními telefony a naprostá většina dnešních telefonů má již GPS navigaci a není zde prípadně potíž si stáhnout aplikace pro využití pokročilejších funkcí souvisejících s GPS. Není zapotřebí speciální př́ístroj. Práce s GPS by mohla doplnit tradiční orientaci v terénu pomocí buzoly, žáci by mohli zaznamenávat určité krajinné prvky do mapy, hodnotit jednotlivá místa a vytvářet tzv. pocitovou mapu či plnit úkoly ve stylu geocachingu. Rovněž by bylo možné zařadit práci s geologickými kladívky, kterými KGE TUL disponuje. Činnost by umožnila žákům si vyzkoušet geologickou práci, poznat mechanické vlastnosti hornin (napřr. poměrně měkkého vápence a tvrdého křemence) a př́padně si připravit vzorky pro geologickou sbírku. Uvedené aktivity by, vzhledem ke snaze o dodržení časového harmonogramu výuky na Ještědu, mohly být zařazeny do plánované výuky v Bedřichově.

\section{Závěr}

Příspěvek představil problematiku terénních cvičení ve výuce zeměpisu na základní škole včetně jejich aktuálních otázek a navrhl řešení ve formě projektu Poznej svưj Liberec, který uplatňuje moderní výukové metody a mezipředmětové vazby. Konkrétně bylo představeno komplexní řešení pro lokalitu Ještěd, přičemž byl vypracován pracovní list pro žáky, metodická př́ručka pro učitele a také mapa lokality.

Autoři usilují o holistický pohled opírající se o premisu, že geografíi je vše, co se odehrává v prostoru. Na rozdíl od klasické výuky ve škole se během terénní výuky jednotlivé předměty harmonicky prolínají a nedochází $\mathrm{k}$ neorganickému přeskakování z tématu na téma. Také je známo, že žáci si odnesou $z$ vhodně připravené a vedené terénní výuky mnohem více nežli ze standardní vyučovací hodiny [4] [8]. Důraz je kladen na získání klíčových kompetencí u žáků a na práci s moderními technologiemi, které jsou dnešní generaci žáků blízké. Zapojení vysokoškolských studentů učitelství zeměpisu přispívá $\mathrm{k}$ tomu, aby jednoho dne vymizely v úvodu př́spěvku zmiňované obavy pedagogů z terénní výuky. Je nutno vyzdvihnout, že projekt byl již ve své pilotní verzi vyzkoušen dvěma základními školami a v nynější podobě členkami BK Variace Liberec a především dvěma třídami ZŠ Kobyly. Zpětná vazba je velmi 
pozitivní, podnětná a vede k dalším inovacím. Nyní, když projekt Poznej svưj Liberec běží a má záśtitu Katedry geografie TUL, spousta libereckých základních škol projevuje o terénní výuku na Ještědu zájem.

Odvážnější ambicí projektu je založení integrovaného odborného pracoviště pro terénní výuku na TUL, které by nabízelo možnost realizace terénní výuky na základních a středních školách v Liberci a jeho okolí, a dále propojení této aktivity s terénní výukou zaměřenou na př́pravu budoucích učitelů zeměpisu $\mathrm{z}$ řad studentů TUL $\mathrm{v}$ rámci předmětů jako Inovace v geografickém vzdělávání nebo Regionální geografie České republiky ve vzdělávání. Podobné geografické pracoviště již existuje při Masarykově univerzitě a je lokalizováno v obci Jedovnice v Moravském krasu.

\section{Poděkování}

Př́spěvek byl vypracován díky finanční podpoře z projektu Učitelem moderně a odborně reg. č. CZ.02.3.68/0.0/0.0/16_038/0006908.

\section{Literatura}

[1] GEOPORTÁL ČÚZK: Geomorfologické jednotky. [online], [cit. 18. 3. 2018]. Dostupné z WWW: https://bit.ly/2MYciGc

[2] GERSMEHL, P.: Teaching geography. Guilford Press, London, 2005. ISBN 978-159385-154-5.

[3] HOFMANN, E.: Integrované terénni vyučování. Paido, Brno, 2003. ISBN 978-807315-054-9.

[4] HOFMANN, E. a kol.: Multimediální učebnice pro terénní výuku. [online]. Masarykova univerzita, Brno, 2008. Dostupné z WWW: https://bit.ly/2KOpeRo

[5] KRATOCHVÍLOVÁ, J.: Teorie a praxe projektové výuky. Masarykova univerzita, Brno, 2016. ISBN 978-80-210-8163-5.

[6] KYŠKA, J: Terénní výuka v zeměpise na 2. stupni ZŠ ve vztahu $k$ českému RVP. Diplomová práce. Technická univerzita v Liberci, Liberec, 2014.

[7] KÜHNLOVÁ, H.: Kapitoly z didaktiky geografie. Karolinum, Praha, 1999. ISBN 97880-7184-995-2.

[8] MARADA, M.: Jak na výuku v terénu. Geografické rozhledy, 2006, roč. XV, č. 3, s. 25. ISSN 1210-3004.

[9] MODRÝ, M.; SÝKOROVÁ, J.: Maloplošná chráněná území Libereckého kraje: PP Terasy Ještědu. Geoprint, Liberec, 2004. ISBN 978-80-239-2838-4.

[10] NÚV: Rámcový vzdělávaci program pro základní vzdělávání. [online]. NÚV, Praha, 2017. Dostupné z WWW: https://bit.ly/2NHK6vU

[11] ROBERTS, M.: Geographic enquiry. Teaching Geography. 2010, roč. XXX, č. 1, s. 69. ISSN 0305-8018.

[12] VÁVRA, J.: Didaktika geografie 1: od vzdělávacího programu $k$ vyučovaci hodině v zemépisu na ZŠ, na př́kladu tématu Světový oceán. Technická univerzita v Liberci, Liberec, 2006.

RNDr. Artur Boháč, Ph.D.; Bc. et Bc. Zuzana Jelínková 


\section{FIELDWORK TEACHING OF GEOGRAPHY FOR BASIC SCHOOLS: REALIZATION ON THE JEŠTĚD MOUNTAIN}

The paper presents a hot issue of fieldwork at basic schools, namely fieldwork in geography. There is often no time to implement fieldwork, or teachers tend to avoid it because of its difficulty. However, fieldwork is embedded in the Framework Education Programme for Basic Education, and its benefits to pupils are unquestionable. The authors, on the example of Ještěd Mountain, show that it is possible to conduct fieldwork with minimal financial and time demands. In the introductory chapters of the contribution, the authors outline the theoretical background of fieldwork in geography education and its position in the Framework Education Programme for Basic Education. Further, on the basis of a survey, they analyze the current solution for field education at basic schools in Liberec. The most important part of the contribution is a comprehensive plan of fieldwork on Ještěd Mountain. Since this teaching has already been implemented, the authors evaluate it. Part of the paper is a map of the locality and samples of the worksheets for pupils.

\section{ERDKUNDE UNTERRICHT IM TERRAIN FÜR GRUNDSCHULEN: DIE VERWIRKLICHUNG AUF JESCHKEN}

Der Beitrag stellt den Lesern die aktuelle Problematik von dem Unterricht im Terrain auf der Grundschule vor, insbesondere dann der Unterricht im Terrain von der Erdkunde. Es kommt häufiger vor, dass der Unterricht im Terrain auf Grund von mangelnder Zeit nicht durchgeführt wird, oder dass dieser Teil durch die Lehrer weggelassen wird, da es als ein anspruchsvoller Teil angesehen wird. Der Unterricht im Terrain ist allerdings durch das Rahmenausbilgsprogramm für Grundschulen festgelegt und seine Vorteile sind nicht zu bezweifeln. Die Autoren beweisen mit dem Beispiel von dem Jeschken Berg, dass sich ausreichende Mittel für den Unterricht im Terrain häufig in der unmittelbaren Nähe von den Schulgebäuden befinden, sodass die Kosten von dieser Unterricht zeitlich und finanziell minimalisiert werden können. In den Einführungskapitolen von dem Beitrag stellen die Autoren den theoretischen Grundlagen vom Unterricht im Terrain im Rahmen von Erkunde vor und beschäftigen sich mit seiner Position im Rahmenausbilgsprogramm für Grundschulen. Anschließend analysieren sie auf Grund von der Untersuchung die aktuellen Lösungen vom Unterricht im Terrain auf Grundschulen in Liberec. Der wichtigste Teil von dem Beitrag stellt dann die komplette Planung vom Unterricht im Terrain auf Jeschken dar. Da dieser Unterricht mittlerweile schon verwirklicht wurde, folgt auch die Evaluation seitens der Autoren. Eine Karte mit den Unterrichtsplätzen und ein Musterblatt vom Schülerarbeitsheft sind ein Teil von dem Beitrag.

\section{NAUKA GEOGRAFII W TERENIE W SZKOŁACH PODSTAWOWYCH: REALIZACJA NA GÓRZE JESZTED}

$\mathrm{W}$ artykule przedstawiono aktualną sytuację w zakresie zajęć dydaktycznych prowadzonych w terenie w szkołach podstawowych na przykładzie zajęć z geografii. Na zajęcia w terenie często nie ma czasu lub nauczyciele ich nie realizują ze względu na trudność ich przeprowadzenia. Zajęcia w terenie są jednak zapisane w Ramowym Programie Dydaktycznym dla kształcenia na poziomie podstawowym. Ponadto niepodważalne są korzyści wynikające z takich zajęć dla uczniów. Autorzy, na przykładzie góry Jeszted, pokazują, że inspiracje do zajęć terenowych można często znaleźć niedaleko budynków szkolnych, a więc takie zajęcia można realizować przy minimalnych nakładach finansowych i czasowych. W początkowych rozdziałach opracowania autorzy przedstawiają teoretyczne podstawy zajęć $\mathrm{w}$ terenie prowadzonych $\mathrm{w}$ ramach nauczania geografii, pokazując zarazem ich pozycję w Ramowym Programie Dydaktycznym dla kształcenia na poziomie podstawowym. Następnie na podstawie przeprowadzonych badań analizują aktualne rozwiązania dotyczące zajęć terenowych funkcjonujące w szkołach podstawowych w Libercu. Najważniejszą częścią opracowania jest kompleksowy plan zajęć terenowych na górze Jeszted. Ponieważ zajęcia te już realizowano, autorzy dokonują ich ewaluacji. Elementem artykułu jest mapa miejsc, w których przeprowadzano zajęcia oraz wybrane elementy kart pracy dla uczniów. 